\title{
STUDI DAYA CERNA ZAT GIZI DAN AKTIVITAS ANTIOKSIDAN TEPUNG KECAMBAH KACANG HIJAU (Phaseolus radiatus L.)
}

\author{
Study of Nutrients Digestibility and Antioxidant Activity of Mung Bean (Phaseolus radiatus L.)
} Sprouts Flour

\author{
Febrielsa Rachmania Rachim $^{1)}$, Ni Wayan Wisaniyasa ${ }^{2}$, AAI Sri Wiadnyani' ${ }^{2)}$ \\ ${ }^{1}$ Mahasiswa Program Studi Imu dan Teknologi Pangan, Fakultas Teknologi Pertanian, Unud \\ ${ }^{2}$ Dosen Program Studi Imu dan Teknologi Pangan, Fakultas Teknologi Pertanian, Unud \\ Kampus Bukit Jimbaran, Badung-Bali
}

\begin{abstract}
The purpose of this study was to determine the nutrient digestibility and antioxidant activity of mung bean sprout flour. This study was conducted using 12 hours germination and without germination of mung bean, and each treatment was repeated three times. Mung bean flour and mung bean sprouts flour were tested for moisture content, ash content, protein content, fat content, carbohydrate content, protein digestibility, starch digestibility, total phenol, and antioxidant activity. The results showed that germination of mung bean had a very significant effect on moisture content, antioxidant activity (IC50), and total phenol, a significant effect on starch digestibility, and had no significant effect on ash content, protein content, fat content, carbohydrate content, and protein digestibility. The results showed that mung bean sprout flour has a moisture content of $6.74 \%$, ash content $3.39 \%$, protein content $32.13 \%$, fat content $11.33 \%$, carbohydrate content $46.41 \%$, protein digestibility $46.80 \%$, starch digestibility $93.45 \%$, total phenol $22.02 \mathrm{mg} / 100 \mathrm{~g}$, and antioxidant activity (IC50) $454.50 \mathrm{ppm}$.
\end{abstract}

Keywords : mung bean, sprout flour, nutrient digestibility, antioxidant activity

\section{PENDAHULUAN}

Indonesia merupakan negara yang kaya akan jenis komoditas yang dapat dikembangkan menjadi berbagai jenis pangan baru. Jenis pangan baru tersebut diharapkan mengandung gizi, sehingga selain rasanya yang lezat untuk dikonsumsi juga dapat bermanfaat bagi kesehatan konsumen. Salah satu jenis kandungan gizi dalam bahan pangan adalah protein. Berdasarkan sumbernya, protein terbagi menjadi 2 yaitu protein nabati dan protein hewani. Kacangkacangan adalah salah satu sumber protein nabati yang sudah dikenal masyarakat.

Kacang hijau termasuk kelompok legum yang merupakan tanaman pangan yang cukup penting di Indonesia karena

Korespondensi Penulis :

E-mail : febrielsarachmania@gmail.com ${ }^{1)}$ mengandung gizi yang bermanfaat bagi tubuh. Setiap 100 gram kacang hijau mengandung pati 67,22 gram, protein 27,10 gram, dan lemak 1,78 gram (Anon., 2009). Pemanfaatan kacang hijau di antaranya kecambah yang dapat dijadikan sayur, asinan, serta yoghurt (Yuliasanjaya, 2010).

Nilai dan mutu gizi kacang-kacangan menjadi lebih baik setelah dikecambahkan (Aminah dan Hersoelistyorini, 2012). Hal ini disebabkan kecambah telah mengalami proses perombakan makromolekul menjadi mikromolekul sehingga meningkatkan daya cerna, di antaranya yakni daya cerna protein dan daya cerna pati. Hal ini dibuktikan bahwa perkecambahan kacang merah selama 48 jam mampu meningkatkan daya cerna kacang 
merah (Wisaniyasa et al., 2017). Hal tersebut terjadi karena selama perkecambahan terjadi proteolisis untuk keperluan tumbuhnya radikel baru. Daya cerna pati meningkat disebabkan pada saat perkecambahan, imbibisi air akan merangsang aktivitas giberelin yang diperlukan untuk mengaktivasi enzim amilase (Zainal, 2013). Selain meningkatkan daya cerna, proses perkecambahan kacang juga mampu mengurangi kadar lemak kacang-kacangan. Hal ini dibuktikan pada perkecambahan kacang merah selama 48 jam yang mampu mengurangi kadar lemak sebesar $38 \%$ (Wisaniyasa dan Suter, 2016).

Perkecambahan kacang juga dapat meningkatkan aktivitas antioksidan (Jaya et al., 2017). Hal tersebut dikarenakan pengaruh terbentuknya beberapa komponen yang berhubungan dengan antioksidan di antaranya fitosterol, vitamin $\mathrm{E}$ ( $\alpha$-tokoferol), senyawa fenol, dan beberapa mineral seperti selenium, tembaga, mangan, seng, dan besi (Astawan, 2005; Winarsi, 2007). Hal ini dibuktikan pada perkecambahan kacang kedelai selama 28 jam di suhu ruang yang mampu meningkatkan aktivitas antioksidan ekstrak tepung kecambah kedelai sebesar $29 \mathrm{mg}$ AEAC/100 g bk (Hazmi, 2016). Perkecambahan kacang merah selama 48 jam pun mampu meningkatkan kapasitas antioksidannya (Wisaniyasa et al., 2017). Peningkatan total fenol dalam biji yang dikecambahkan selalu diiringi dengan peningkatan aktivitas antioksidannya (Jaya et al., 2017). Hal ini terjadi karena selama proses germinasi terjadi peningkatan zat-zat nutrisi yang termasuk senyawa-senyawa fenol yang merupakan bagian dari senyawa antioksidan.

Kecambah memiliki umur simpan yang pendek, maka perlu dilakukan upaya lain untuk memperpanjang umur simpannya. Penepungan merupakan alternatif produk setengah jadi yang dianjurkan karena memiliki daya simpan yang lebih panjang, dapat dicampur dengan jenis tepung lain, dan mudah untuk dilakukan proses selanjutnya menjadi produk pangan siap konsumsi.

Penelitian tentang daya cerna zat gizi dan aktivitas antioksidan tepung kecambah kacang hijau belum pernah dilakukan. Berdasarkan latar belakang tersebut perlu dilakukan penelitian ini dengan tujuan untuk mengetahui daya cerna zat gizi dan aktivitas antioksidan tepung kecambah kacang hijau.

\section{METODE PENELITIAN}

\section{Tempat dan Waktu}

Penelitian ini akan dilaksanakan di Laboratorium Pengolahan Pangan dan Laboratorium Analisis Pangan Fakultas Teknologi Pertanian Universitas Udayana, dan untuk pengujian daya cerna protein dan daya cerna pati dilaksanakan di Laboratorium Pangan dan Gizi Fakultas Teknologi Pertanian Universitas Gadjah Mada. Penelitian dilaksanakan pada bulan JuliOktober 2018.

\section{Bahan dan Alat}

Bahan-bahan yang digunakan dalam melaksanakan penelitian ini terdiri dari bahan baku dan bahan kimia. Bahan baku terdiri dari kacang hijau yang diperoleh dari pedagang di daerah Padangsambian, Denpasar Barat. Bahan kimia yang digunakan dalam melakukan analisis meliputi $\mathrm{H}_{2} \mathrm{SO}_{4}, \mathrm{NaOH}$, $\mathrm{HCl}$, heksan, alkohol 96\%, tablet Kjeldahl, asam borat, buffer Walpole, enzim $\alpha$-amilase, pereaksi DNS (dinitrosalisilat), larutan buffer Na-fosfat, larutan maltose standar, enzim pepsin, TCA (trikloroasetat), indikator PP, etanol absolut, aquades, reagen FolinCiocalteau, sodium karbonat, methanol, dan DPPH.

Alat-alat yang digunakan dalam melaksanakan penelitian ini antara lain timbangan analitik (Shimadzu), oven (Memmert), kertas saring, erlenmeyer, cawan porselin, tabung reaksi, batang pengaduk, 
desikator, corong, pipet tetes, labu takar, buret, muffle (Daihan), destilator, spektrofotometer UV-VIS (Thermo Scientific Genesis 10S), kuvet, gelas beker, pipet volume, labu kjeldahl, soxhlet, vortex, aluminium foil, spatula, dan pipet mikro, cabinet dryer (Blue M).

\section{Rancangan Percobaan}

Rancangan yang digunakan pada penelitian ini adalah eksperimental dengan 2 perlakuan yakni kacang hijau tanpa perkecambahan dan kacang hijau dengan perkecambahan.

$$
\begin{array}{ll}
\text { F1 } & \text { Tanpa perkecambahan } \\
\text { F2 } & =\text { Perkecambahan }
\end{array}
$$

Masing-masing perlakuan diulang sebanyak 3 kali sehingga diperoleh 6 unit percobaan.

\section{Pelaksanaan Penelitian}

\section{Pembuatan Tepung Kacang Hijau}

Kacang hijau disortasi kemudian dilakukan pencucian. Setelah dicuci bersih kacang hijau direndam selama kurang lebih 3 jam. Proses pencucian dan perendaman dilakukan dalam waskom. Setelah 3 jam, kacang hijau ditiriskan. Kacang hijau yang telah direndam kemudian dikeringkan dengan cabinet dryer bersuhu $50^{\circ} \mathrm{C}$ selama 24 jam. Lalu dilakukan proses penggilingan dengan blender. Setelah itu, hasil penggilingan diayak dengan ayakan 60 mesh hingga didapat tepung yang diinginkan.

\section{Pembuatan Tepung Kecambah Kacang Hijau}

Kacang hijau disortasi kemudian dicuci. Setelah dicuci bersih kacang hijau direndam selama kurang lebih 3 jam. Setelah itu kacang hijau dikecambahkan selama 12 jam dalam keranjang plastik yang dialasi dan ditutupi daun pisang. Kemudian, kecambah kacang hijau yang telah jadi dikeringkan dengan cabinet dryer bersuhu $50^{\circ} \mathrm{C}$ selama 24 jam.
Lalu dilakukan proses penggilingan dengan blender. Setelah itu, hasil penggilingan diayak dengan ayakan 60 mesh hingga didapat tepung yang diinginkan.

\section{Variabel yang Diamati}

Variabel yang diamati dalam penelitian ini meliputi kadar air dilakukan dengan analisis metode pengeringan, kadar abu dengan analisis metode pengabuan, kadar protein dengan analisis metode mikrokjeldahl, kadar lemak dengan analisis metode soxhlet, kadar karbohidrat dengan analisis carbohydrate by different (Sudarmadji et al., 1997), daya cerna protein dengan analisis metode in vitro (Tanaka et al., 1978), daya cerna pati dengan analisis metode in vitro (Muchtadi, 1989), total fenol dengan analisis metode Folin-Ciocalteau (Sakanaka et al., 2003), dan aktivitas antioksidan dengan analisis metode DPPH (Sompong et al., 2011).

Analisis data yang digunakan untuk membedakan daya cerna zat gizi dan aktivitas antioksidan antara tepung kacang hijau yang tidak dikecambahkan dengan tepung kecambah kacang hijau adalah dengan uji - T (Stell and Torrie, 1995).

\section{HASIL DAN PEMBAHASAN}

Hasil penelitian menunjukkan bahwa perkecambahan berpengaruh sangat nyata terhadap kadar air, aktivitas antioksidan (IC50), dan total fenol, berpengaruh nyata terhadap daya cerna pati, namun berpengaruh tidak nyata terhadap kadar abu, kadar protein, kadar lemak, kadar karbohidrat, dan daya cerna protein. 


\section{Hasil Analisis Proksimat Tepung Kacang Hijau dan Tepung Kecambah Kacang Hijau}

Data hasil analisis proksimat tepung kacang hijau dan tepung kecambah kacang hijau dapat dilihat pada Tabel 1.

Tabel 1. Hasil Analisis Proksimat Tepung Kacang Hijau dan Tepung Kecambah Kacang Hijau

\begin{tabular}{lccc}
\hline Parameter & $\begin{array}{c}\text { Tepung } \\
\text { Kacang } \\
\text { Hijau }\end{array}$ & $\begin{array}{c}\text { Tepung } \\
\text { Kecambah } \\
\text { Kacang } \\
\text { Hijau }\end{array}$ & $\begin{array}{c}\text { Hasil T- } \\
\text { test }\end{array}$ \\
\hline $\begin{array}{l}\text { Kadar Air } \\
(\%)\end{array}$ & $7,45 \pm 0,06$ & $6,74 \pm 0,05$ & $* *$ \\
$\begin{array}{l}\text { Kadar Abu } \\
(\%)\end{array}$ & $3,55 \pm 0.59$ & $3,39 \pm 0.60$ & ns \\
$\begin{array}{l}\text { Kadar } \\
\text { Protein }(\%)\end{array}$ & $29,88 \pm 0.59$ & $32,13 \pm 0.82$ & ns \\
$\begin{array}{l}\text { Kadar } \\
\text { Lemak (\%) }\end{array}$ & $12.64 \pm 0.65$ & $11,33 \pm 0.18$ & ns \\
$\begin{array}{l}\text { Kadar } \\
\text { Karbohidrat } \\
(\%)\end{array}$ & $46,48 \pm 0,36$ & $46,41 \pm 0,93$ & ns \\
\hline
\end{tabular}

Ket : ns $=$ non signifikan (berpengaruh tidak nyata)

*) = berpengaruh nyata

**) berpengaruh sangat nyata

\section{Kadar Air}

Hasil analisis data menunjukkan bahwa perkecambahan berpengaruh sangat nyata $(\mathrm{P}<0,01)$ terhadap kadar air tepung kecambah kacang hijau. Tabel 1 menunjukkan bahwa kadar air tepung kacang hijau sebesar 7,45\% dan tepung kecambah kacang hijau sebesar $6,74 \%$. Kadar air pada tepung kecambah kacang hijau lebih rendah diduga disebabkan karena proses perendaman dan perkecambahan mengakibatkan peningkatan permeabilitas dinding sel sehingga difusi air lebih mudah dan komponen terlarut keluar dari bahan (Muchtadi dan Sugiyono, 1992). Pada saat perendaman, biji kacang hijau juga mengalami pembengkakan yang menyebabkan struktur di dalamnya akan menjadi lebih renggang sehingga ketika dikeringkan pada saat proses pembuatan tepung, air akan lebih mudah hilang. Pembengkakan granula yang tidak dapat kembali ke bentuk semula cenderung memiliki rongga antar sel yang lebih besar sehingga selama pengeringan air yang dikandung lebih mudah terlepas (Winata, 2001). Hal ini didukung oleh penelitian Anita (2009) yang menyebutkan bahwa perkecambahan mampu menurunkan kadar air tepung kacang komak. Penelitian Hazmi (2016) juga menyatakan bahwa perkecambahan dapat menurunkan kadar air tepung kacang kedelai.

\section{Kadar Abu}

Kacang-kacangan merupakan sumber mineral yang baik di antaranya besi, kalsium, seng, tembaga, kalium dan magnesium (Anita, 2009). Besarnya kadar abu dalam suatu bahan menunjukkan kadar mineral yang terkandung di dalamnya. Semakin besar kadar abu suatu bahan maka semakin besar pula mineral yang dikandungnya. Hasil analisis data menunjukkan bahwa perkecambahan berpengaruh tidak nyata $(\mathrm{P}>0,05)$ terhadap kadar abu tepung kecambah kacang hijau. Pada penelitian ini terjadi penurunan kadar abu namun tidak berbeda signifikan secara statistik diduga disebabkan karena lama perkecambahan yang hanya 12 jam.

\section{Kadar Protein}

Hasil analisis data menunjukkan bahwa perkecambahan berpengaruh tidak nyata $(\mathrm{P}>0,05)$ terhadap kadar protein tepung kecambah kacang hijau. Pada penelitian ini terjadi peningkatan kadar protein namun tidak berbeda signifikan secara statistik kemungkinan disebabkan karena lama perkecambahan yang hanya $12 \mathrm{jam}$, di mana peningkatan zat-zat gizi pada kecambah mulai tampak pada waktu optimum perkecambahan 
yakni sekitar 24-48 jam (Hazmi, 2016). Hal ini didukung oleh penelitian Lombu et al., (2018) yang mengungkapkan bahwa kadar protein tepung jagung meningkat secara signifikan dengan perlakuan perkecambahan selama 36 jam. Penelitian Wisaniyasa dan Suter (2016) juga menyatakan bahwa perkecambahan selama 48 jam mampu meningkatkan kadar protein tepung kacang merah secara signifikan.

\section{Kadar Lemak}

Hasil analisis data menunjukkan bahwa perkecambahan berpengaruh tidak nyata $(\mathrm{P}>0,05)$ terhadap kadar lemak tepung kecambah kacang hijau. Penelitian Lombu (2018) juga menunjukkan adanya penurunan kadar lemak secara signifikan sebesar $0,41 \%$ pada tepung kecambah jagung dengan lama perkecambahan 36 jam yang memiliki kadar lemak sebesar $4,76 \%$, dan tepung jagung tanpa perkecambahan memiliki kadar lemak sebesar $5,17 \%$. Penurunan kadar lemak disebabkan selama proses perkecambahan, lemak yang merupakan cadangan makanan digunakan sebagai sumber energi.

\section{Kadar Karbohidrat}

Hasil analisis data menunjukkan bahwa perkecambahan berpengaruh tidak nyata $(\mathrm{P}>0,05)$ terhadap kadar karbohidrat tepung kecambah kacang hijau. Pada penelitian ini, penurunan kadar karbohidrat kemungkinan dikarenakan karbohidrat tersebut digunakan sebagai sumber energi selama proses perkecambahan. Karbohidrat dijadikan sebagai sumber energi oleh makhluk hidup. Kadar karbohidrat kacang-kacangan umumnya berkisar antara 24\%-68\%. Karbohidrat ini termasuk mono-, di-, oligosakarida, pati, serta komponen polisakarida (Salunkhe, et al., 1985).
Hasil Analisis Daya Cerna Protein, Daya Cerna Pati, Aktivitas Antioksidan, serta Total Fenol Tepung Kacang Hijau dan Tepung Kecambah Kacang Hijau

Data hasil analisis daya cerna protein, daya cerna pati, aktivitas antioksidan, serta total fenol tepung kacang hijau dan tepung kecambah kacang hijau dapat dilihat pada Tabel 2.

Tabel 2. Hasil Analisis Daya Cerna Protein, Daya Cerna Pati, Aktivitas Antioksidan, serta Total Fenol Tepung Kacang Hijau dan Tepung Kecambah Kacang Hijau

\begin{tabular}{lccc}
\hline Parameter & $\begin{array}{c}\text { Tepung } \\
\text { Kacang } \\
\text { Hijau }\end{array}$ & $\begin{array}{c}\text { Tepung } \\
\text { Kecambah } \\
\text { Kacang } \\
\text { Hijau }\end{array}$ & $\begin{array}{c}\text { Hasil } \\
\text { T- } \\
\text { test }\end{array}$ \\
\hline $\begin{array}{l}\text { Daya Cerna } \\
\text { Protein (\%) }\end{array}$ & $44,98 \pm 0,66$ & $46,80 \pm 0,77$ & ns \\
$\begin{array}{l}\text { Daya Cerna } \\
\text { Pati (\%) }\end{array}$ & $88,56 \pm 0,62$ & $93,45 \pm 0,98$ & $*$ \\
Aktivitas & $559,40 \pm 14,22$ & $454,50 \pm 3,22$ & $* *$ \\
$\begin{array}{l}\text { Antioksidan } \\
\text { (IC50) ppm }\end{array}$ & & & \\
$\begin{array}{l}\text { Total Fenol } \\
\text { (mg/100 g) }\end{array}$ & $19,44 \pm 0,56$ & $22,02 \pm 0,45$ & $* *$ \\
\hline
\end{tabular}

Ket : $\quad$ ns $=$ non signifikan (berpengaruh tidak nyata) *) berpengaruh nyata

**) berpengaruh sangat nyata

\section{Daya Cerna Protein}

Hasil analisis data menunjukkan bahwa perkecambahan berpengaruh tidak nyata $(\mathrm{P}>0,05)$ terhadap daya cerna protein tepung kecambah kacang hijau. Daya cerna protein adalah kemampuan suatu protein untuk dapat dihidrolisis menjadi asam-asam amino oleh enzim-enzim pencernaan (Muchtadi, 1989). Daya cerna protein tepung kacang hijau yang tidak dikecambahkan dengan tepung kecambah kacang hijau tidak signifikan secara statistik diduga disebabkan adanya pengaruh peningkatan total fenol. Hal ini disebabkan senyawa fenol seperti polifenol mampu 
menghambat aktivitas enzim tripsin (Elias, 1979; Fernandez, 1975; dan Ordones, 1976 dalam Bressani et al., 1982). Penghambatan ini dikarenakan enzim tripsin tidak dapat mengenali substrat seperti protein akibat terbentuknya kompleks yang kuat antara polifenol dan protein. Senyawa kompleks ini tersusun dari gugus hidroksi dan karboksilat yang menyebabkan protein lebih sulit dihidrolisis oleh enzim pencernaan (Himmah dan Handayani, 2012).

\section{Daya Cerna Pati}

Hasil analisis data menunjukkan bahwa perkecambahan berpengaruh nyata $(\mathrm{P}<0,05)$ terhadap daya cerna pati tepung kecambah kacang hijau. Tabel 2 menunjukkan daya cerna pati tepung kacang hijau sebesar $88,56 \%$, dan daya cerna pati tepung kecambah kacang hijau sebesar 93,45\%.

Daya cerna pati adalah tingkat kemudahan pati untuk dapat dihidrolisis oleh enzim pemecah pati menjadi unit-unit yang lebih sederhana (Sede et al., 2015). Pada tepung kecambah kacang hijau terjadi peningkatan daya cerna pati karena pada saat kacang berkecambah terjadi hidrolisis karbohidrat menjadi molekul yang lebih sederhana sehingga mudah dicerna (Astawan, 2009). Daya cerna pati meningkat disebabkan pada saat perkecambahan, imbibisi air akan merangsang aktivitas giberelin yang diperlukan untuk mengaktivasi enzim amilase. Enzim ini selanjutnya akan bekerja dengan mengkatalis proses perubahan cadangan makanan di mana pati akan menjadi gula yang akan digunakan sebagai sumber energi (Zainal, 2013). Pada penelitian sebelumnya mengenai tepung kecambah jagung dengan lama perkecambahan 36 jam, daya cerna pati juga mengalami peningkatan dibandingkan dengan tepung jagung sebesar $5,39 \%$ yaitu dari $57,04 \%$ menjadi $62,43 \%$ (Lombu, 2018). Hal ini didukung oleh pernyataan Kamil (1979) yang menyatakan bahwa saat perkecambahan terjadi degradasi senyawa kompleks yang bersifat tidak larut menjadi senyawa sederhana yang bersifat larut dalam air seperti glukosa dan asam amino yang diperlukan dalam pertumbuhan radikel baru.

\section{Total Fenol}

Hasil analisis data menunjukkan bahwa perkecambahan berpengaruh sangat nyata $(\mathrm{P}<0,01)$ terhadap total fenol tepung kecambah kacang hijau. Tabel 2 menunjukkan total fenol tepung kacang hijau sebesar 19,44 mg/100 g, dan total fenol tepung kecambah kacang hijau sebesar 22,02 $\mathrm{mg} / 100 \mathrm{~g}$.

Fenol merupakan salah satu komponen antioksidan yang ada dalam kecambah. Selama proses perkecambahan, senyawa fenol dan komponen antioksidan lainnya dapat terbentuk sehingga dapat meningkatkan total fenol kacang hijau (Astawan, 2005). Meningkatnya total fenol kemungkinan disebabkan oleh aktivitas enzimatik. Hal ini didukung oleh penelitian Wisaniyasa et al., (2017) yang menunjukkan adanya peningkatan total fenol pada kacang merah yang dikecambahkan. Peningkatan total fenol dalam biji kedelai hitam yang dikecambahkan diiringi dengan peningkatan aktivitas antioksidannya (Pertiwi et al., 2013). Hal ini terjadi karena senyawa fenol merupakan bagian dari senyawa antioksidan.

\section{Aktivitas Antioksidan (IC50)}

Hasil analisis data menunjukkan bahwa perkecambahan berpengaruh sangat nyata $(\mathrm{P}<0,01)$ terhadap aktivitas antioksidan (IC50) tepung kecambah kacang hijau. Tabel 3 menunjukkan aktivitas antioksidan (IC50) tepung kacang hijau sebesar 559,40 ppm, dan aktivitas antioksidan (IC50) tepung kecambah kacang hijau sebesar 454,50 ppm, di mana semakin rendah nilai IC50 suatu bahan menunjukkan kemampuan bahan tersebut untuk menghambat radikal bebas semakin baik.

Perkecambahan kacang dapat meningkatkan aktivitas antioksidan (Jaya et 
al., 2017). Hal tersebut dikarenakan pengaruh terbentuknya beberapa komponen yang berhubungan dengan antioksidan di antaranya fitosterol, vitamin $\mathrm{E}$ ( $\alpha$-tokoferol), senyawa fenol, dan beberapa mineral seperti selenium, tembaga, mangan, seng, dan besi (Astawan, 2005; Winarsi, 2007). Peningkatan senyawa fenol biasanya diiringi dengan peningkatan aktivitas antioksidan. Penelitian Hazmi (2016) membuktikan pada perkecambahan kacang kedelai selama 28 jam mampu meningkatkan aktivitas antioksidan ekstrak tepung kecambah kedelai sebesar $29 \mathrm{mg}$ AEAC/100 g bk.

\section{KESIMPULAN DAN SARAN}

\section{Kesimpulan}

Berdasarkan hasil penelitian yang dilakukan maka dapat disimpulkan hal-hal sebagai berikut :

1. Perkecambahan berpengaruh sangat nyata terhadap kadar air, aktivitas antioksidan (IC50), dan total fenol, berpengaruh nyata terhadap daya cerna pati, namun berpengaruh tidak nyata terhadap kadar abu, kadar protein, kadar lemak, kadar karbohidrat, dan daya cerna protein.

2. Tepung kecambah kacang hijau memiliki kadar air sebesar 6,74\%, kadar abu $3,39 \%$, kadar protein 32,13\%, kadar lemak 11,33\%, kadar karbohidrat $46,41 \%$, daya cerna protein $46,80 \%$, daya cerna pati $93,45 \%$, total fenol 22,02 $\mathrm{mg} / 100 \mathrm{~g}$, dan aktivitas antioksidan (IC50) 454,50 ppm.

\section{Saran}

Berdasarkan hasil penelitian disarankan untuk adanya penelitian lebih lanjut mengenai daya cerna zat gizi tepung kecambah kacang hijau dengan waktu perkecambahan yang berbeda.

\section{DAFTAR PUSTAKA}

Aminah, S., dan W. Hersoelistyorini. 2012. Karakteristik Kimia Tepung Kecambah Serealia dan Kacangkacangan dengan Variasi Blanching. Seminar Hasil-Hasil Penelitian. ISBN : 978-602-18809-0-6. Program Studi Teknologi Pangan Universitas Muhammadiyah Semarang. Semarang.

Anita, S. 2009. Studi Sifat Fisikokimia Sifat Fungsional Karbohidrat dan Aktivitas Antioksidan Tepung Kecambah Kacang Komak (Lablab purpureus (L) sweet ). Skripsi. Tidak Dipublikasikan. Institut Pertanian Bogor. Bogor.

Anonimus. 2009. Tabel Komposisi Pangan Indonesia. Persatuan Ahli Gizi Indonesia. PT. Elex Media Komputindo. Jakarta.

Astawan, M. 2005. Kacang Hijau, Antioksidan yang Membantu Kesuburan Pria. http://web.ipb.ac.id/ tpg/de/pubde_ntr tnhlth_kacanghijau.php. Diakses pada tanggal 28 November 2017. Denpasar.

Astawan, M. 2009. Sehat dengan Hidangan Kacang dan Biji-bijian. Penebar Swadaya. Jakarta.

Hazmi, K. 2016. Karakteristik Fisikokimia Tepung Kecambah Kedelai dan Tepung Kedelai. Skripsi. Departemen Ilmu dan Teknologi Pangan, Fakultas Teknologi Pertanian, Institut Pertanian Bogor. Bogor.

Jaya, M.M., M. Lestary, dan Y.A. Wani. 2017. Perbedaan aktivitas antioksidan kecambah beras coklat (Oryza sativa L.) berdasarkan lama proses elisitasi 
dan waktu perkecambahan. Indonesian Journal of Human Nutrition. 4(2): 108-116.

Kamil, J. 1979. Teknologi Benih I. Angkasa. Bandung.

Lombu, W.K., N.W. Wisaniyasa, dan A.A.I.S. Wiadnyani. 2018. Perbedaan karakteristik kimia dan daya cerna pati tepung jagung dan tepung kecambah jagung (Zea mays L.). Jurnal ITEPA. 7(1): 43-51.

Muchtadi, D. 1989. Evaluasi Nilai Gizi Pangan. Pusat Antar Universitas Pangan dan Gizi Universitas Gadjah Mada. Yogyakarta.

Muchtadi, T.R., dan Sugiyono. 1992. Petunjuk Praktikum: Ilmu dan Pengetahuan Bahan Pangan. PAU Pangan dan Gizi IPB. Bogor.

Pertiwi, S.F., S. Aminah, dan Nurhidajah. 2013. Aktivitas antioksidan, karakteristik kimia, dan sifat organoleptik susu kecambah kedelai hitam (Glycine soja) berdasarkan variasi waktu perkecambahan. Jurnal Pangan dan Gizi. 4(8): 1-8.

Sakanaka, S., Y. Tachibana., dan Y. Okada. 2003. Preparation and antioxidant properties of extracts of japanese persimo leaf tea (kakinocha-cha). Food Chemistry. 89: 569-575.

Salunkhe, D.K., S.S. Kadam, dan J.K. Cavan. 1985. Postharvest Biotechnology of Food Legumes. CRC Press. Boca Raton, Florida.

Sede, V.J., C.F. Mamuaja, dan G.S.S Djarkasi. 2015. Kajian sifat fisik kimia beras analog pati sagu baruk modifikasi HMT (Heat Moisture Treatment) dengan penambahan tepung komposit. Jurnal Ilmu dan Teknologi Pangan. 3(2): 24-35.

Sompong, R., S. Siebenhandl-Ehn, G. Linsberger-Martin, dan E. Berghofer. 2011. Physicochemical and antioxidative properties of red and black rice varieties from Thailand, China, and Sri Lanka. J. Food Chem. 124: 132-140.

Stell, R.G.D. dan J.H. Torrie. 1995. Prinsip dan Prosedur Statistika Suatu Pendekatan Biometrik. PT. Gramedia Pustaka Utama. Jakarta. (diterjemahkan oleh B. Sumantri).

Sudarmadji, S., B. Haryono, dan Suhardi. 1997. Prosedur Analisis untuk Bahan Makanan dan Pertanian. Liberty. Yogyakarta.

Sudarmanto, S. 1992. Perubahan Kecernaan Protein Keping Biji Kedelai Akibat Perkecambahan. Laporan Penelitian. Fakultas Teknologi Pertanian Universitas Gadjah Mada. Yogyakarta.

Tanaka, Y., A.P. Resurreccion, B.O. Juliano, dan D.B. Bechtel. 1978. Properties of whole and undigested fraction of protein bodies of milled rice. Agric. Biol. Chem. 42: 2013-2023.

Winarsi, H. 2007. Antioksidan Alami dan Radikal Bebas. Kanisius. Yogyakarta.

Winarsi, H. 2010. Protein Kedelai dan Kecambah. Kanisius. Bandung.

Winata, A.Y. 2001. Karakterisasi Tepung Sukun (Artocarpus altilis) Pramasak Hasil Pengeringan Drum Serta Aplikasinya Untuk Substitusi Tepung Terigu Pada Pembuatan Roti Manis. 
Skripsi. Institut Pertanian Bogor. Bogor.

Wisaniyasa, N.W. dan I.K. Suter. 2016. Kajian sifat fungsional dan kimia tepung kecambah kacang merah (Phaseolus vulgaris L.). Jurnal Media Ilmiah Teknologi Pangan. 3(1): 26-34.

Wisaniyasa, N.W., A.S. Duniaji, dan A.A.G.N.A. Jambe. 2017. Studi daya cerna protein, aktivitas antioksidan, dan sifat fungsional tepung kecambah kacang merah (Phaseolus vulgaris L.) dalam rangka pengembangan pangan fungsional. Jurnal Media Ilmiah Teknologi Pangan. 4(2): 122- 129.

Yuliasanjaya, B. 2010. Pembuatan Yoghurt Susu Kecambah Kacang Hijau. Skripsi. Fakultas Teknologi Industri Pertanian Universitas Pembangunan Nasional Veteran. Jawa Timur.

Zainal, A.R. 2013. Amilase Pada Kecambah Kacang Merah dan Kacang Bunci Hitam (Phaseolus vulgaris L.). Fakultas MIPA. Universitas Lampung. 